\title{
Photoreactivation in two freshwater ciliates: differential responses to variations in UV-B flux and temperature
}

\author{
Robert W. Sanders ${ }^{1, *}$, Amy L. Macaluso ${ }^{1}$, Thomas J. Sardina ${ }^{1}$, David L. Mitchell ${ }^{2}$ \\ ${ }^{1}$ Biology Department, Temple University, Philadelphia, Pennsylvania 19122, USA \\ ${ }^{2}$ University of Texas M.D. Anderson Cancer Center, Science Park/Research Division, Smithville, Texas 78957, USA
}

\begin{abstract}
The effects of UV-B radiation on 2 ciliate species (Glaucoma sp. and Cyclidium sp.) from a clear oligotrophic lake were examined under laboratory conditions with and without photoreactivating radiation (PRR: UV-A and visible light). Glaucoma sp. was exposed to 3 UV-B intensities at 4 temperatures to simulate a range of environmentally relevant conditions. Population growth of Glaucoma sp. declined with increasing levels of UV-B exposure in treatments receiving PRR; blocking PRR generally resulted in $100 \%$ mortality. Occurrence of cyclobutane pyrimidine dimers (CPDs $[\mathrm{mb} \mathrm{DNA}]^{-1}$ ) was significantly reduced in Glaucoma sp. receiving PRR relative to those without PRR. These data indicate that photoenzymatic repair is a major component of UV-B tolerance in Glaucoma. At UV-B levels that Glaucoma sp. tolerated, Cyclidium sp. suffered $100 \%$ mortality and accumulated a similar level of CPDs whether or not PRR was blocked. Incubation of the 2 ciliates under UV-transparent and UV-blocking acrylics in the oligotrophic lake confirmed their relative sensitivities to UV radiation (UVR). Photoenzymatic repair in Glaucoma sp. was more efficient at $20^{\circ} \mathrm{C}$ than at 10,15 and $25^{\circ} \mathrm{C}$. The temperature-dependent nature of photoenzymatic repair underscores the need to consider the interactive effects of temperature and UVR on biota, particularly in the face of global climate change and rising incident UVR due to ozone depletion.
\end{abstract}

KEY WORDS: Ultraviolet radiation - UV-B - Photoreactivation - Photoenzymatic repair - Ciliates · Cyclobutane pyrimidine dimers $\cdot$ Temperature $\cdot$ Glaucoma $\cdot$ Cyclidium

\section{INTRODUCTION}

Erosion of the stratospheric ozone layer has altered the influx of solar ultraviolet radiation in recent years and caused a disproportional increase in the amount of damaging ultraviolet-B (UV-B, 280 to $320 \mathrm{~nm}$ ) reaching aquatic systems in polar and temperate latitudes (Rex et al. 1997, Madronich et al. 1998, Houghton et al. 2001). UV-B penetration into the water column is highly variable, with $1 \%$ attenuation depths ranging from a few centimeters to $>10 \mathrm{~m}$. Differences in UV-B attenuation result from multiple factors that include living and detrital particulates, $\mathrm{pH}$, salinity and chromophoric dissolved organic matter (CDOM) concentrations (Morris et al. 1995, Schindler et al. 1996, Arts et al. 2000). Despite the potential for strong vertical gradients of damaging ultraviolet radi- ation and consequential depth refugia from UV-B exposure in aquatic systems, negative effects of UV-B including inhibition of photosynthesis and damage to nuclear DNA are well documented in marine and freshwater organisms (Neale et al. 1998b, Sommaruga \& Buma 2000, Zagarese et al. 2003, MacFadyen et al. 2004).

Absorption of UV-B by DNA disrupts its structureprimarily by formation of pyrimidine dimers - which interferes with replication and transcription (Mitchell \& Karentz 1993). Once damage to DNA is incurred, it can be offset by several molecular repair mechanisms. Photoreactivation, or photoenzymatic repair (PER), is a taxonomically widespread, but not ubiquitous, DNA repair process that removes cyclobutane pyrimidine dimers from damaged DNA. PER requires the enzyme CPD photolyase plus photoreactivating radiation (PRR: 
ultraviolet-A [UV-A, 320 to $400 \mathrm{~nm}$ ] and/or visible light [400 to $700 \mathrm{~nm}$ ]). The second most prevalent type of DNA damage from UV-B, the (6-4) pyrimidine-pyrimidone dimer, is much less common but potentially more damaging than the CPD to DNA structure (Mitchell 2004). Photoenzymatic repair of (6-4) dimer lesions has been reported for many organisms; however, the efficiency of (6-4) photolyase is very low compared with CPD photolyase (Mitchell 2004). In addition to lightdependent DNA repair, there are multi-step enzymatic repair mechanisms (such as nucleotide excision repair, NER) that do not require light. These dark-repair mechanisms are increasingly important in organisms with reduced PER (Mitchell 1995).

UV-B damage to DNA has generally been found to be independent of temperature (Cadet \& Vigny 1990, Pakker et al. 2000), but as an enzyme-dependent process, PER is expected to have an optimum temperature range. Consequently, increases in global temperature (Houghton et al. 2001) and increases in the incident flux of solar ultraviolet radiation may have interactive effects on species and populations by modifying the balance of DNA damage and repair (Williamson et al. 2002). Additionally, changes in global temperature and atmospheric ozone may interact in unexpected ways to alter ecosystem-level processes including biogeochemical cycling and trophic structure (Bothwell et al. 1994, Rae \& Vincent 1998, Shindell et al. 1998, Pienitz \& Vincent 2000, Zepp et al. 2003). Irrespective of the effects of climate change on regional temperature, temperature and UV intensity vary seasonally and can undergo rapid change over relatively small vertical distances in the water column of lakes and oceans. Thus, the potential interactions of temperature with currently increasing levels of UV-B should be considered when predicting the effects of ozone depletion on aquatic systems.

Ciliate species are globally distributed in aquatic ecosystems and are important components of planktonic food webs (Sanders \& Wickham 1993, Finlay et al. 1999, Jürgens et al. 1999), yet relatively little is known about the effect of UV radiation on these heterotrophic protists (Sommaruga \& Buma 2000). This study presents results from laboratory experiments designed to elucidate interactive effects of ultraviolet radiation and temperature on ciliates from an oligotrophic lake. The efficacy of photoenzymatic repair in the ciliate Glaucoma sp. was altered by changing temperature and UV-B intensity over environmentally relevant ranges. Cyclidium sp., another ciliate isolated from the same water sample as Glaucoma sp., was much more sensitive to UV-B exposure and showed no evidence of photoenzymatic repair. These data add to the growing evidence of species-specific responses to UV-B exposure.

\section{MATERIALS AND METHODS}

Maintenance of cultures. Two freshwater ciliates, Glaucoma sp. and Cyclidium sp., were isolated from enrichment cultures of a water sample collected in October 1999 at a depth of $3.5 \mathrm{~m}$ from the pelagic zone $\left(z_{\max }=23 \mathrm{~m}\right)$ of Lake Giles $\left(41^{\circ} 23^{\prime} \mathrm{N}, 75^{\circ} 06^{\prime} \mathrm{W}\right)$. Lake Giles is an optically clear oligotrophic lake $\left(k_{\mathrm{d} 305}=\right.$ $0.4 \mathrm{~m}^{-1} ; k_{\mathrm{d} \text { PAR }}=0.13$, where PAR = photosynthetically active radiation) in the Pocono Mountains region of eastern Pennsylvania, USA (Morris et al. 1995). The ciliates were identified to genus using light microscopy and by comparison of sequences of the 18S ssrRNA gene using BLAST against the GenBank nucleotide database. Glaucoma sp. and Cyclidium sp. showed greatest sequence similarity to G. chattoni $(97 \%)$ and to C. glaucoma (98\%), respectively. Partial sequences obtained in this study have been deposited in GenBank (Accession Nos. DQ090841 and DQ090842 for Cyclidium sp. and Glaucoma sp., respectively). Stock cultures were kept at $20^{\circ} \mathrm{C}$ with a $14: 10 \mathrm{~h}$ light:dark regime (cool white fluorescent bulbs). The culture medium was $0.05 \%$ Cerophyll $^{\circledR}$ adjusted to a pH of 6.0, with an unidentified bacterial isolate from the original enrichment culture present as food.

UV-lamp phototron. Laboratory experiments were performed in a controlled-temperature walk-in chamber using a UV-lamp phototron to expose the 2 species of ciliates to damaging UV-B radiation in the presence and absence of longer wavelength photoreactivating radiation (PRR). The lamp phototron consists of a horizontally rotating wheel set flush into a circular opening in the top of an opaque box containing sources of PRR (visible and UV-A radiation supplied by two $40 \mathrm{~W}$ cool white fluorescent bulbs and two $40 \mathrm{~W}$ Q-Panel 340 fluorescent bulbs, respectively). The box is ventilated with a high-speed fan. UV-B radiation is provided from above the box by a Spectroline XX15B UV-B lamp (Spectronics). The shortest wavelengths of UV-B and UV-C radiation not present in incident solar radiation were filtered out by covering the UV-B lamp with a cellulose acetate sheet that was replaced after every $12 \mathrm{~h}$ exposure.

The wheel has circular openings for up to 40 custommade flat-bottomed quartz dishes $(50 \mathrm{~mm}$ diameter, approximately $18 \mathrm{~mm}$ deep, $30 \mathrm{ml}$ volume) with quartz lids. Dishes can be exposed to damaging UV-B and repair radiation sources separately, by blocking 1 light source with an opaque disk, or simultaneously by removing the disks. A black skirt around the wheel and PVC collars surrounding each dish minimize stray radiation among dishes. The spectral composition of the damaging and repair radiation was checked at $1 \mathrm{~nm}$ resolution with a custom-made spectral radiometer by C. E. Williamson (Williamson et al. 2001). Further details of the UV lamp phototron approach, including 
spectral information of the lamps, have been described elsewhere (Grad et al. 2001, Williamson et al. 2001).

General experimental design. The overall design was to expose ciliates to different intensities of UV-B radiation in the presence or absence of PRR at several temperatures. Exposures were for a single $12 \mathrm{~h}$ period, after which all treatments were maintained in the dark. By following population growth after exposure in the lamp phototron, tolerance of UV-B could be separated into 2 components: dark repair plus photoprotection, and photoenzymatic repair. Survivorship and population growth in treatments that did not receive PRR were attributed to dark repair mechanisms or photoprotection; increased survival or growth in treatments receiving PRR compared to treatments without PRR is attributed here to photoenzymatic repair.

Stainless steel mesh covers placed over the quartz lids of individual dishes modified the levels of damaging radiation from the UV-B lamp. At a given temperature (see next paragraph), the levels of ultraviolet radiation from the UV-B lamp were 100, 78, and $40 \%$ of maximum; the total exposures over a $12 \mathrm{~h}$ period were 58,45 and $23 \mathrm{~kJ} \mathrm{~m}^{-2}$ (primarily in the 295 to $320 \mathrm{~nm}$ range). All references to the UV exposures refer to the total UV from the Spectroline XX15B lamp, ignoring contribution from the lamps used to supply PRR. For comparison, the irradiance spectrum of the UV-B lamp was weighted by the Setlow DNA action spectrum integrated across 285 to $339 \mathrm{~nm}$ and normalized to $300 \mathrm{~nm}$ (Setlow 1974). Equivalent Setlowweighted exposures with the different meshes were 9.7, 7.5 and $3.9 \mathrm{~kJ} \mathrm{~m}^{-2}$, respectively. An additional treatment with a UV-B intensity of $11 \mathrm{~kJ} \mathrm{~m}^{-2}(1.8 \mathrm{~kJ}$ $\mathrm{m}^{-2}$ Setlow-weighted) was added for Cyclidium sp., and a final experiment that further reduced the UV-B lamp intensity to $6 \mathrm{~kJ} \mathrm{~m}^{-2}\left(0.97 \mathrm{~kJ} \mathrm{~m}^{-2}\right.$ Setlowweighted) by adding mesh directly over the UV-B lamp was performed for both species at $20^{\circ} \mathrm{C}$. Each treatment and control was run in triplicate in all experiments. The maximum UV exposure (100\%) over $12 \mathrm{~h}$ was approximately equal to ambient UV exposure on a sunny day around summer solstice at $40^{\circ} \mathrm{N}$ latitude when weighted for the spectral sensitivity of the cladoceran Daphnia pulicaria (Williamson et al. 2001).

For Glaucoma sp., experiments were run at 10, 15, 20 and $25^{\circ} \mathrm{C}$ to span the range of environmentally relevant temperatures that the ciliates would encounter in Lake Giles. Cyclidum sp. was tested for its response to UV-B exposure only at 20 and $25^{\circ} \mathrm{C}$ because preliminary tests indicated negligible growth at $15^{\circ} \mathrm{C}$. Ciliates were preadapted to experimental temperatures for 3 to $5 \mathrm{~d}$. Ciliates in logarithmic growth phase were transferred from the pre-adapted stock culture to $0.22 \mu \mathrm{m}$-filtered Lake Giles water and adjusted to a targeted initial abundance of 500 to 1000 ciliates $\mathrm{ml}^{-1}$. Since UV radiation could have a direct negative effect on live bacteria, and consequently have an indirect effect on the ciliates via food limitation, heat-killed bacteria ( $\mathrm{HKB}$ ) were added as a food source at a final concentration of approximately $1 \times 10^{7} \mathrm{HKB} \mathrm{ml} \mathrm{m}^{-1}$. Preliminary experiments demonstrated that both ciliate species had similar growth dynamics in the Cerophyll ${ }^{\circledR}$ medium with live bacteria and in sterile-filtered lakewater from Lake Giles supplemented with HKB.

Ciliate abundance was determined from $3.5 \mathrm{ml}$ samples taken at $0 \mathrm{~h}$ (prior to UV exposure), $12 \mathrm{~h}$ (end of UV exposure), 24, 48, 72, and $96 \mathrm{~h}$, and preserved with Lugol's iodine. Prior to fixation, each sample was examined for ciliate movement and morphology since changes in these parameters have been previously identified as potential sublethal effects of UV radiation in protozoans (Sommaruga et al. 1996). Ciliates were enumerated at $400 \times$ using Utermöhl chambers on a Zeiss Axiovert microscope.

Heat-killed bacteria. A culture of the bacterium Pasteurella sp. was grown to late exponential growth in $0.1 \%$ yeast extract and killed by heating the culture in a $70^{\circ} \mathrm{C}$ water bath for $1 \mathrm{~h}$ (Sanders et al. 1990). All subsequent steps for HKB preparation used aseptic techniques. The killed cells were centrifuged in sterile $250 \mathrm{ml}$ bottles at $8000 \mathrm{rpm}(8230 \times g)$ for $20 \mathrm{~min}$. Pellets were resuspended in autoclaved distilled water and the wash step was repeated. HKB were then filtered through a sterile $5 \mu \mathrm{m}$ Nuclepore filter to remove aggregated cells and were further dispersed by a probe sonicator immediately prior to addition to experiments. Sterility of HKB was checked at the beginning of each experiment by inoculation into $0.1 \%$ yeast extract.

DNA damage. To confirm that DNA damage in ciliates exposed to UV-B was consistent with presumed repair mechanisms and growth responses, additional experiments were performed following the standard UV-lamp phototron procedure. Replicate quartz dishes of Cyclidium sp. and Glaucoma sp. were exposed to UV-B at the maximum level $\left(58 \mathrm{~kJ} \mathrm{~m}^{-2}\right)$ with or without PER at $20^{\circ} \mathrm{C}$ over a $12 \mathrm{~h}$ time course. Controls for background levels of photoproduct consisted of replicate dishes kept in the dark during the exposure period. Immediately after exposure, ciliates were collected on Nuclepore polycarbonate filters and stored frozen until DNA was extracted from the cells. Concentrations of cyclobutane pyrimidine dimer (CPD) photoproducts of DNA damage were then quantified by radioimmunoassay (Mitchell 1996).

Exposure to natural solar radiation. Glaucoma sp. and Cyclidium sp. were exposed to natural solar radiation in Lake Giles on successive sunny days in late June 2001 (5 and 6 d after summer solstice). Stock cultures were grown in incubators under fluorescent light at 
$23^{\circ} \mathrm{C}$ in $0.2 \mu \mathrm{m}$-filtered Lake Giles water supplemented with HKB. Ciliates were diluted to several hundred per milliliter with filtered lake water plus HKB in UV-transparent Bitran polyethylene bags (5 replicate bags per treatment) in the laboratory and transported to Lake Giles in coolers. Bags were suspended at a depth of $0.5 \mathrm{~m}$ under flat sheets of UV-blocking acrylic (OP-2, CYRO) or UV-transparent acrylic (OP-4, CYRO). Water temperature during incubations was $23^{\circ} \mathrm{C}$. Glaucoma sp. was exposed for $8 \mathrm{~h}$ beginning at 08:00 h Eastern Standard Time (EST), while the more UV-sensitive Cyclidium sp. was exposed for $4 \mathrm{~h}$ beginning at 09:30 $\mathrm{h}$ EST the following day. After exposure, the bags were returned to the laboratory and maintained at $23^{\circ} \mathrm{C}$ in the dark for an additional $48 \mathrm{~h}$. Samples for microscopic enumeration were fixed with Lugol's iodine at the beginning and end of the exposure periods, and at 24 and $48 \mathrm{~h}$ post-exposure.

Statistical treatments. The significance of UV-B intensity levels and temperature
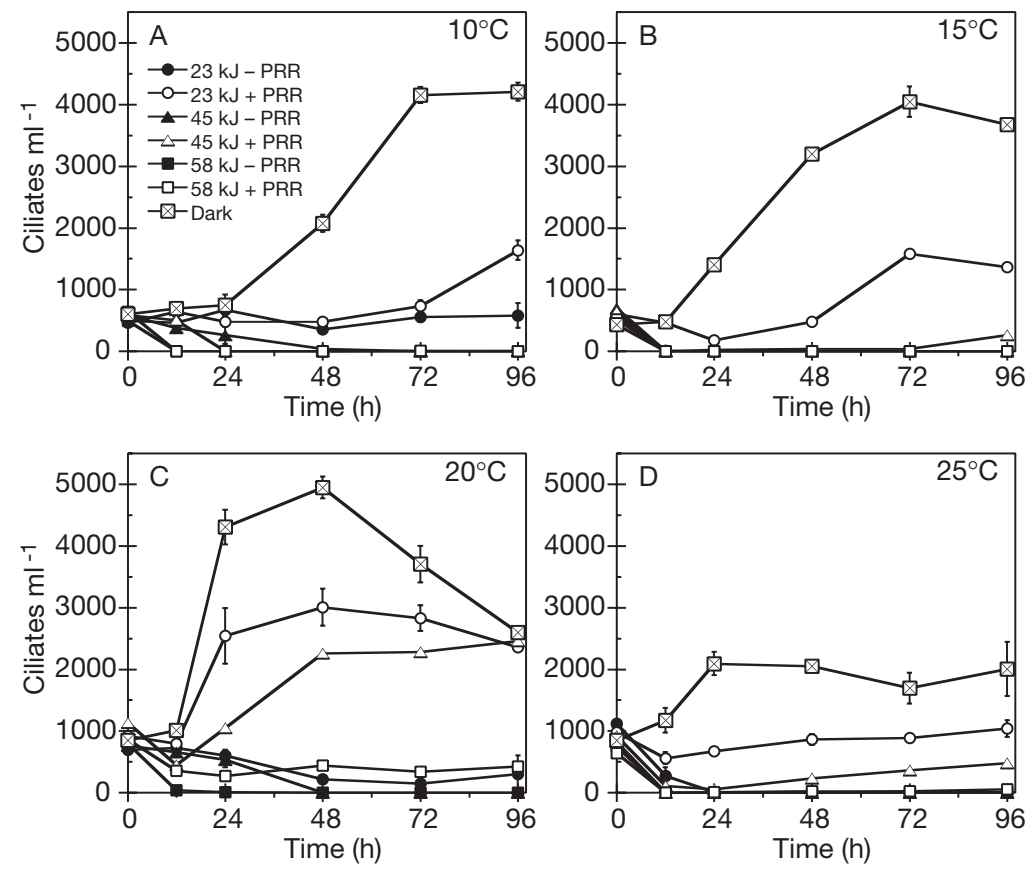

Fig. 1. Glaucoma sp. Changes in the abundance (ciliates $\mathrm{ml}^{-1} \pm \mathrm{SE}$ ) after exposure to UV-B with $(+)$ or without $(-)$ photorepair radiation (PRR) at different temperatures $\left(\mathrm{kJ}=\mathrm{kJ} \mathrm{m}^{-2}\right)$ on maximum population sizes (as percentages of dark controls) and on the efficiency of photoenzymatic repair (growth rates in treatments receiving PRR) were tested using 2-way ANOVA. Prior to analyses, data were (square root +1 )transformed for growth rates and arcsine-transformed for relative (percent) population size.

\section{RESULTS}

Glaucoma sp. and Cyclidium sp. varied dramatically in their responses to UV-B exposure in the presence and absence of photoreactivating radiation. When exposed to UV-B, population growth of both species

Table 1. Glaucoma sp. Maximum specific growth rate $\left(\mathrm{d}^{-1}\right)$ $($ mean $\pm \mathrm{SE}, \mathrm{n}=3)$. UV-B $\left(\mathrm{kJ} \mathrm{m}^{-2}\right)$ lamp exposures were with $(+)$ or without (-) photoreactivating radiation (PRR). S: some survival, but no growth; M: complete mortality

\begin{tabular}{|lcccc|}
\hline \multirow{2}{*}{ UV-B } & \multicolumn{5}{c|}{ Temperature $\left({ }^{\circ} \mathrm{C}\right)$} \\
\cline { 2 - 5 } & 10 & 15 & 20 & 25 \\
\hline Dark & $0.88 \pm 0.13$ & $1.2 \pm 0.15$ & $2.9 \pm 0.08$ & $1.3 \pm 0.35$ \\
$23+$ PRR & $0.82 \pm 0.16$ & $0.70 \pm 0.13$ & $2.3 \pm 0.39$ & $0.91 \pm 0.39$ \\
$23-\mathrm{PRR}$ & $\mathrm{S}$ & $\mathrm{M}$ & $\mathrm{S}$ & $\mathrm{S}$ \\
$45+\mathrm{PRR}$ & $\mathrm{S}$ & $\mathrm{S}$ & $1.1 \pm 0.03$ & $0.47 \pm 0.03$ \\
$45-\mathrm{PRR}$ & $\mathrm{M}$ & $\mathrm{M}$ & $\mathrm{M}$ & $\mathrm{M}$ \\
$58+\mathrm{PRR}$ & $\mathrm{M}$ & $\mathrm{M}$ & $0.13 \pm 0.19$ & $\mathrm{~S}$ \\
$58-\mathrm{PRR}$ & $\mathrm{M}$ & $\mathrm{M}$ & $\mathrm{M}$ & $\mathrm{M}$ \\
& & & & \\
\hline
\end{tabular}

was generally inhibited relative to dark controls, but Glaucoma sp. survived and grew at much higher exposure levels than Cyclidium sp.

Glaucoma sp. had the highest growth rate and reached the maximum population size in dark controls (Table 1, Fig. 1). When exposed to UV-B without PRR, it usually suffered complete mortality although survival without population growth was sometimes observed (Table 1). After UV-B exposure, growth rate and survival were both temperature dependent with maxima at $20^{\circ} \mathrm{C}$. Glaucoma sp. in the dark controls at $20^{\circ} \mathrm{C}$ had the highest maximum growth rate $\left(\mu_{\max }=\right.$ $2.9 \mathrm{~d}^{-1}$ ) and abundance (approximately 5000 cells $\mathrm{ml}^{-1}$ ) relative to any combination of UV-B exposure and temperature (Table 1, Fig. 1). The effects of UV-B intensity and temperature on growth rates were both significant $(p<0.001)$, and ANOVA indicated a significant interaction effect.

The most efficient photoenzymatic repair also was observed at $20^{\circ} \mathrm{C}$, where Glaucoma sp. grew or survived at all UV-B exposure levels in treatments that received PRR (Fig. 2). There was a trend of increasing maximum growth rate and maximum population size with decreasing UV-B exposure level if PRR was present (Table 1, Fig. 1C). Equivalent exposure levels without PRR resulted in $100 \%$ mortality except for the lowest exposure treatments. In the lowest UV-B plus PRR treatment $\left(23 \mathrm{~kJ} \mathrm{~m}^{-2}\right)$ at $20^{\circ} \mathrm{C}$, Glaucoma sp. had 


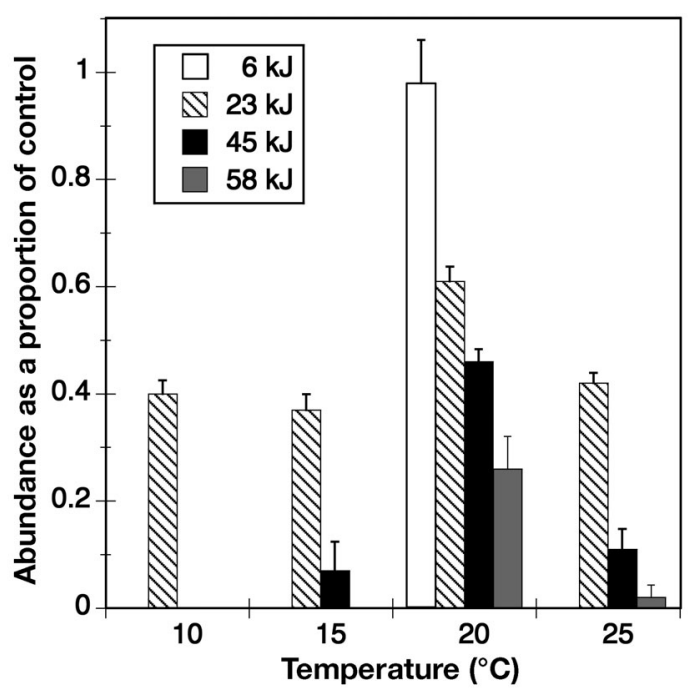

Fig. 2. Glaucoma sp. Maximum abundance as a proportion of dark controls during exposure to different temperatures and levels of UV-B in the presence of photorepair radiation

the greatest growth rate $\left(\mu_{\max }=2.3 \mathrm{~d}^{-1}\right)$ of any UV-B treatment (Table 1). Maximum specific growth rates in the 45 and $58 \mathrm{~kJ} \mathrm{~m}^{-2} \mathrm{UV}-\mathrm{B}$ exposures with PRR were significantly reduced $\left(\mu_{\max }=1.1 \mathrm{~d}^{-1}\right.$ and $0.13 \mathrm{~d}^{-1}$, respectively). In the experiment in which UV-B exposure was reduced to $6 \mathrm{~kJ} \mathrm{~m}^{-1}$, Glaucoma sp. reached the same abundance in dark controls and treatments with PRR (Fig. 2). Without PRR, exposure to 45 and $58 \mathrm{~kJ} \mathrm{~m}^{-2}$ UV-B resulted in $100 \%$ mortality within 24 to $48 \mathrm{~h}$ (Table 1). At $23 \mathrm{~kJ} \mathrm{~m}^{-2}$ without PRR, abundance declined to about $150 \mathrm{ml}^{-1}$ and no population growth occurred during the experiment (Fig. 1). Survival was much greater at $6 \mathrm{~kJ} \mathrm{~m}^{-1}$, but even at this lowest exposure level growth in treatments without PRR was negligible.

For any given treatment, population growth rates and/or survival declined when incubation temperature was increased or decreased from $20^{\circ} \mathrm{C}$ (Table 1). At $25^{\circ} \mathrm{C}$, Glaucoma sp. growth rate in the control was $45 \%$ of the $20^{\circ} \mathrm{C}$ control; similar inhibition was observed for the 45 and $58 \mathrm{~kJ} \mathrm{~m}^{-2}$ with PRR treatments relative to those treatments at $20^{\circ} \mathrm{C}$ (Table 1). The maximum abundance at $25^{\circ} \mathrm{C}$ was significantly lower compared to the $20^{\circ} \mathrm{C}$ experiment, and survival in treatments without PRR was observed only at the lowest level of UV-B exposure at $25^{\circ} \mathrm{C}$ (Fig. 1D). At $15^{\circ} \mathrm{C}$, the maximum specific growth rates in the dark control and in the $23 \mathrm{~kJ} \mathrm{~m}^{-2}$ with PRR treatment were not significantly different from those treatments at $25^{\circ} \mathrm{C}$ (Table 1). There was no population growth at $15^{\circ} \mathrm{C}$ in the $58 \mathrm{~kJ} \mathrm{~m}^{-2}$ with PRR treatment. However, after the initial decline in abundance in the $45 \mathrm{~kJ} \mathrm{~m}^{-2}$ with PRR, a small but stable population of survivors was present and there was a small increase in ciliate abundance during the last $24 \mathrm{~h}$ of the experiment (Fig. 1B). At $10^{\circ} \mathrm{C}$, positive growth was observed only in the dark control and at the lowest UV-B level tested $\left(23 \mathrm{~kJ} \mathrm{~m}^{-2}\right)$, while there was $100 \%$ mortality within 12 to $48 \mathrm{~h}$ at higher exposures of UV-B (Fig. 1A). Glaucoma sp. in the dark controls at $10^{\circ} \mathrm{C}$ showed a moderate growth rate during the $96 \mathrm{~h}$ sampling period $\left(\mu_{\max }=0.88 \mathrm{~d}^{-1}\right)$, and reached a maximum abundance of approximately 4000 ciliates $\mathrm{ml}^{-1}$ (Fig. $1 \mathrm{~A}$ ). In the $10^{\circ} \mathrm{C}$ treatment with $23 \mathrm{~kJ} \mathrm{~m}^{-2} \mathrm{UV}-\mathrm{B}$ plus PRR, abundance was indistinguishable from that in the minus-PRR treatment until the 72 to $96 \mathrm{~h}$ time period, when growth over the final $24 \mathrm{~h}$ of the experiment was $0.82 \mathrm{~d}^{-1}$ (Table 1, Fig. 1A).

The major trends in the lamp-phototron experiments with Glaucoma sp. can be summarized by comparing the maximum cell abundance in each treatment receiving $P R R$ to the maximum abundance in the dark control at that temperature. Maximum abundance relative to the control occurred at the lowest exposure level at every temperature tested. At $20^{\circ} \mathrm{C}$ and an exposure of $6 \mathrm{~kJ} \mathrm{~m}^{-2}$ from the UV-B lamp, abundance was not significantly different between the control and plus PRR treatment (Fig. 2). At 15, 20 and $25^{\circ} \mathrm{C}$, abundance relative to control decreased with increasing UV-B intensity. At $10^{\circ} \mathrm{C}$, the ciliates did not survive the higher levels of UVR exposure (Table 1), but their abundance relative to the dark control in the $23 \mathrm{~kJ} \mathrm{~m}^{-2}$ plus PRR was similar to that at $15^{\circ} \mathrm{C}$ (Fig. 2). Both temperature and UV-B intensity had significant effects on the maximum population size in the presence of PRR ( $p<0.001)$, and ANOVA also indicated a significant interaction component $(\mathrm{p}<0.001)$.

Cyclidium sp. was much more sensitive to UV-B exposure than Glaucoma sp., and suffered complete mortality in the 58 and $23 \mathrm{~kJ} \mathrm{~m}^{-2}$ treatments with and without added PRR at both 20 and $25^{\circ} \mathrm{C}$ (Table 2). Experiments were not performed at lower temperatures for this species because preliminary experiments indicated very low population growth at $15^{\circ} \mathrm{C}$. When Cyclidium sp. was exposed to $11 \mathrm{~kJ} \mathrm{~m}^{-2}$ of UV-B, survival was observed in treatments with and without

Table 2. Cyclidium sp. Maximum abundance (percentage of the dark control) during exposure to UV-B $\left(\mathrm{kJ} \mathrm{m}^{-2}\right)$ lamps with $(+)$ or without $(-)$ photoreactivating radiation (PRR) at 20 and $25^{\circ} \mathrm{C}$; mean $\pm \mathrm{SE}, \mathrm{n}=3$. M: complete mortality; $\mathrm{nd}=$ no data

\begin{tabular}{|lcccc|}
\hline \multirow{2}{*}{ UV-B } & \multicolumn{2}{c}{$20^{\circ} \mathrm{C}$} & \multicolumn{2}{c|}{$25^{\circ} \mathrm{C}$} \\
& + PRR & - PRR & + PRR & - PRR \\
\hline 6 & $96 \pm 8$ & $42 \pm 2$ & nd & nd \\
11 & $21 \pm 1$ & $51 \pm 7$ & $18 \pm 5$ & $39 \pm 5$ \\
23 & $\mathrm{M}$ & $\mathrm{M}$ & $\mathrm{M}$ & $\mathrm{M}$ \\
58 & $\mathrm{M}$ & $\mathrm{M}$ & $\mathrm{M}$ & $\mathrm{M}$ \\
& & & & \\
\hline
\end{tabular}


PRR. The population size remained relatively stable in treatments without PRR, but declined in the presence of PRR at both 20 and $25^{\circ} \mathrm{C}$. Finally, at an exposure level of $6 \mathrm{~kJ} \mathrm{~m}^{-2}$, Cyclidium sp. survived and grew in all treatments. However, population growth was much greater in the treatment with PRR and, as with Glaucoma sp., the maximum abundance observed at $6 \mathrm{~kJ}$ $\mathrm{m}^{-2}$ with PRR was not significantly different from the dark control (Table 2). In treatments without PRR, Cyclidium sp. reached a maximum abundance of only $42 \%$ of the dark control, indicating that population growth was inhibited in the absence of photoenzymatic repair at the lowest UV exposure.

Cyclobutane pyrimidine dimers per megabase DNA $\left(\mathrm{CPDs} \mathrm{Mb}^{-1}\right)$ were elevated in both species of ciliates exposed to UV-B at $58 \mathrm{~kJ} \mathrm{~m}^{-1}$ relative to background levels in the dark controls (Table 3). For Glaucoma sp., treatments receiving photoreactivating radiation had significantly fewer CPDs $\mathrm{Mb}^{-1}$ than those without PRR

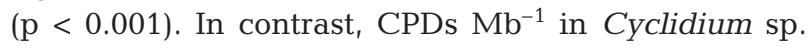
were not significantly different in treatments with and without PRR (Table 3).

Results from exposure to natural solar radiation at Lake Giles confirmed the relative sensitivity to UV radiation observed in the laboratory experiments with the 2 ciliate species. Populations of Cyclidium sp. exposed to full sunlight decreased precipitously during and after exposure, while those shielded from UV with OP-2 acrylic grew rapidly (Table 4). Growth rates of Glaucoma sp. under UV-shielded and UV-transparent acrylic were positive and indistinguishable from each other (Table 4).

Table 3. Glaucoma sp. and Cyclidium sp. Cyclobutane pyrimidine dimers per megabase $\left(\mathrm{CPD} \mathrm{Mb}^{-1}\right)$ during maximum experimental UV-B $\left(\mathrm{kJ} \mathrm{m}^{-2}\right)$ lamp exposure with $(+)$ and without $(-)$ photoreactivating radiation (PRR) at $20^{\circ} \mathrm{C}_{\text {; }}$ mean $\pm \mathrm{SE}, \mathrm{n}=3$

\begin{tabular}{|lcc|}
\hline UV-B & Glaucoma sp. & Cyclidium sp. \\
\hline Dark & $2.0 \pm 0.3$ & $1.9 \pm 0.2$ \\
$58+$ PRR & $6.5 \pm 1.7$ & $23 \pm 12$ \\
$58-$ PRR & $29 \pm 5$ & $18 \pm 5$ \\
\hline
\end{tabular}

Table 4. Glaucoma sp. and Cyclidium sp. Growth rates $\left(\mathrm{d}^{-1}\right)$ during exposure to natural solar radiation at a depth of $0.5 \mathrm{~m}$ in Lake Giles in June. UV-exposed treatments were incubated under UV-transparent acrylic (OP-4, CYRO), and UVshielded treatments under UV-blocking acrylic (OP-2, CYRO)

\begin{tabular}{|lcr|}
\hline Treatment & Glaucoma sp. & Cyclidium sp. \\
\hline UV-exposed & $1.6 \pm 0.03$ & $-1.4 \pm 0.48$ \\
UV-shielded & $1.6 \pm 0.14$ & $1.6 \pm 0.18$ \\
\hline
\end{tabular}

\section{DISCUSSION}

\section{Effects of UV-B and repair radiation}

Deleterious effects of UV-B, including damage to DNA, appear to be species-specific among protists (Karentz et al. 1991, Wickham \& Carstens 1998, Sommaruga \& Buma 2000). The ciliate Stentor coerulus was sensitive to UVR exposure, but $S$. araucanus showed no difference in the proportion of survivors when treatments were shielded from UVR (Häder \& Häder 1991, Modenutti et al. 1998). Likewise, changes in population sizes during incubations of pond communities from Greenland indicated strong negative effects of UV-B on the ciliates Askenasia sp. and Bursaridium sp., moderate negative effects on the ciliates Halteria sp. and Strombidium sp., and no apparent effect on Urotricha sp. (Wickham \& Carstens 1998). Direct negative effects of UV radiation, in the form of accumulated DNA damage, also shows differences across protistan taxa. Sommaruga \& Buma (2000) found that the heterotrophic flagellates Bodo saltans and $B$. caudatus accumulated greater DNA damage after UV-B exposure than chrysomonad or cryptomonad flagellates, and a Cyclidium sp. did not accumulate any CPDs after a Setlow-weighted UV-B exposure of $1.69 \mathrm{~kJ} \mathrm{~m}^{-2}$. By comparison, growth of the Cyclidium sp. isolated from Lake Giles was inhibited by exposure at $11 \mathrm{~kJ} \mathrm{~m}^{-2}$, but not at $6 \mathrm{~kJ} \mathrm{~m}^{-2}$ (Setlowweighted, 1.8 and $0.97 \mathrm{~kJ} \mathrm{~m}^{-2}$, respectively) from our UV-B lamp with photorepair radiation (Table 2). The Glaucoma sp. and Cyclidium sp. examined here also had very different tolerances to UV-B and accumulated different levels of DNA damage (CPDs) despite being isolated from the same water sample.

The variation in UV sensitivity between protistan species is likely to reflect differences in both physiology and behavior. Various strategies for avoiding damage from UV radiation known in other eukaryotes are also known in protists. Attenuation in the water column would reduce the negative effects of UV-B for species that either remain in deep water or migrate deeper into the water column during peak daylight hours. Several species of ciliates appear to detect and avoid UV-B radiation (Barcelo \& Calkins 1979, Lenci et al. 1997), although this does not appear to be the case for the species of Glaucoma and Cyclidium examined here. Experiments in $20 \mathrm{~cm}$ columns indicated that vertical distributions for both Glaucoma sp. and Cyclidium sp. exposed to unidirectional illumination from UV lamps or natural sunlight were no different from UV-shielded or dark controls after 1 to $2.5 \mathrm{~h}$ (A. L. Macaluso pers. obs.). Some organisms also use photoprotective agents to prevent or reduce UV-induced damage. Production of mycosporine-like amino acids 
(MAA) and carotenoids that absorb strongly in the UV range of the spectrum are known for a variety of photosynthetic protists (Neale et al. 1998a, Jeffrey et al. 1999), and these compounds along with their photoprotective utility can be passed to consumers (Rocco et al. 2002, Moeller et al. 2005). To our knowledge there is no indication that any heterotrophic ciliates produce photoprotective compounds, and extractions of the experimental food source (HKB) in $25 \%$ aqueous methanol showed no absorption peaks in the UV portion of the spectrum (data not shown). Even when avoidance behavior or photoprotection are apparent in organisms, neither is $100 \%$ effective, and the ability to repair UV-induced damage to DNA should be as widespread in protists as it is in other organisms (Mitchell \& Karentz 1993, Blaustein et al. 1994, Malloy et al. 1997, Grad et al. 2001).

Photoenzymatic repair (PER) - a major mechanism for mending DNA damage caused by UV-B radiation-has been demonstrated for the ciliate Paramecium tetraurelia, some photosynthetic dinoflagellates (Smith-Sonneborn 1979, Litchman et al. 2002), and in Antarctic diatoms (Karentz et al. 1991). Karentz et al. (1991) found that DNA repair was enhanced in the presence of PRR in several diatoms; however, the importance of PER relative to 'dark repair' mechanisms such as NER is relatively unknown for protists. Use of the lamp phototron allowed separation of photorepair wavelengths from UV-B, thus allowing evaluation of PER relative to other mechanisms of UV tolerance. The increased survival, growth rates and final abundances of Glaucoma sp. in the treatments receiving PRR relative to those without PRR (Table 1, Fig. 1) strongly suggest that PER is an important component of the overall tolerance of UV-B for this species. Without PRR, Glaucoma sp. suffered $100 \%$ mortality when exposed to UV-B at intensities $>23 \mathrm{~kJ} \mathrm{~m}^{-2}$; at $23 \mathrm{~kJ} \mathrm{~m}^{-2}$ without PRR, populations either declined to a low stable abundance with no apparent growth or died out (Table 1). Even at the lowest level of UV-B tested $\left(6 \mathrm{~kJ} \mathrm{~m}^{-2}\right.$ at $20^{\circ} \mathrm{C}$ ) growth without PRR was very low (data not shown), while populations with PRR were indistinguishable from the dark controls (Fig. 2). Further evidence of the importance of PER to Glaucoma sp. is the significantly reduced accumulation of CPDs in the presence of PRR (Table 3).

In contrast to Glaucoma sp., Cyclidium sp. showed little tolerance of UV-B and photoenzymatic repair played a reduced role. UV-B exposures at which Glaucoma sp. had positive population growth resulted in $100 \%$ mortality for Cyclidium sp., irrespective of PRR (Table 2). The similar accumulations of CPDs in populations of Cyclidium sp. exposed to UV-B with or without PRR indicate that PER was very inefficient in this ciliate (Table 3). Only at the lowest UV-B exposure tested $\left(6 \mathrm{~kJ} \mathrm{~m}^{-2}\right)$ did Cyclidium sp. grow better in the presence of PRR. At $11 \mathrm{~kJ} \mathrm{~m}^{-2}$, Cyclidium sp. survived but did not grow, and its abundance was reduced more in the presence of PRR than in its absence (Table 2). Since exposure of Cyclidium sp. to PRR alone did not significantly inhibit growth relative to dark controls (data not shown) and harmful consequences of PER exposure was not apparent at $6 \mathrm{~kJ} \mathrm{~m}^{-2}$, the negative effect of PRR in the presence of $11 \mathrm{~kJ} \mathrm{~m}^{-2}$ of UV-B suggests that UV-A and UV-B may act as multiple stressors in this species. Sensitivity to UV-A is known for many species, including several heterotrophic and photosynthetic protists. The freshwater kinetoplatid flagellate Bodo saltans, and 2 marine flagellates, Paraphysomonas bandaiensis and $P$. imperforata, had reduced motility and feeding when exposed to UV-A radiation alone or in combination with UV-B (Sommaruga et al. 1996, Ochs 1997, Ochs \& Eddy 1998). Reduced motility was also reported for the ciliate Stentor coeruleus in treatments exposed to the UV-A portion (320 to $400 \mathrm{~nm}$ ) of natural solar radiation relative to treatments exposed only to wavelengths $>400 \mathrm{~nm}$ (Häder \& Häder 1991). Alternatively, the small amount of UV-B emitted by the UVA-340 lamps supplying PRR (MacFadyen et al. 2004) may have had an additive effect that exceeded a threshold in Cyclidium sp. for UV-B tolerance.

\section{Temperature effects on recovery from UV exposure}

Within species-specific ranges, metabolism of protists and growth rate are generally positively related to temperature (Caron et al. 1990, Jones \& Rees 1994). The maximum specific growth rate $\left(\mu_{\max }\right)$ of Glaucoma sp. calculated for dark controls follows this trend and increases with increasing temperature from $10^{\circ} \mathrm{C}$ through $20^{\circ} \mathrm{C}$. At $25^{\circ} \mathrm{C}, \mu_{\max }$ was reduced to approximately the same value as at $15^{\circ} \mathrm{C}$, suggesting that optimal growth in this strain of Glaucoma occurs at $20^{\circ} \mathrm{C}$. If DNA damage from UV-B were largely independent of temperature, but enzymatically driven repair of UV-B damage were not, changing temperature would be expected to alter the ratio of damage to repair (Williamson et al. 2002). The results from our experiments support this suggestion. At the optimum temperature for growth $\left(20^{\circ} \mathrm{C}\right)$, Glaucoma sp. populations grew at every UV-B level, but the maximum abundance decreased with increasing UV-B intensity (Fig. 2). When Glaucoma sp. was acclimated to experimental temperatures greater or less than $20^{\circ} \mathrm{C}$, maximum abundance relative to controls decreased at all UV-B intensities (Fig. 2), indicating that PER (i.e. photolyase activity) was less effective at temperatures that were non-optimal for growth. 
Several earlier studies observed temperature-dependent responses to UV radiation by aquatic organisms. Repair of UV-B-induced DNA damage by both PER and NER showed temperature optima in the marine red alga Palmaria palmata (Pakker et al. 2000), and the rate of PER increased with increasing temperature in the estuarine killifish Fundulus heteroclitus (Malloy et al. 1997). Malloy et al. (1997) also noted efficient PER in krill and 2 Antarctic fish at temperatures $\leq 1^{\circ} \mathrm{C}$. Survival of freshwater zooplankton after exposure to UVB also showed temperature optima, with greatest survival of the copepod Leptodiaptomus minutus and the cladoceran Daphnia catawba at $25^{\circ} \mathrm{C}$, and the rotifer Asplanchna girodi at $20^{\circ} \mathrm{C}$ (Williamson et al. 2002). Another cladoceran, D. pulicaria, was found to have increasingly efficient PER at $25^{\circ} \mathrm{C}$ compared to 5 and $15^{\circ} \mathrm{C}$, although temperature effects were not significant for NER (MacFadyen et al. 2004). Thus, the data for Glaucoma sp. fit a general trend, excepting the stenothermal Antarctic species, for an increasing efficiency of PER with increasing temperature within a species-specific range.

\section{Implications for aquatic systems}

The effect of temperature on enzymatic repair of UV damage has ramifications on scales beyond individual organisms. For example, environmental seasonal variations in ambient UV radiation and water temperatures can lead to a strong variation in UV:temperature ratios (UV:T). In Lake Giles, where our cultures of Glaucoma sp. and Cyclidium sp. originated, the highest UV:T conditions occur in spring (March and April) when UV begins increasing and temperatures remain cold; UV:T is lower in summer (June to August) because both temperature and UV influx are high (Williamson et al. 2002). Although our lamp phototron does not exactly simulate solar radiation, it approximates a range of exposures to UV radiation that are relevant to Lake Giles (Williamson et al. 2001). We do not have data for seasonal distributions of these species in Lake Giles, other than incidental observations of Glaucoma sp. in depth-integrated samples during the early summer and both species in surface waters in October when they were isolated. Our data for Glaucoma sp. suggest that it is likely to be most susceptible to UV exposure at extremes of UV:T ratios because its survival at a given UV exposure is reduced at both low and high temperatures (Figs. $1 \& 2$ ). The Cyclidum sp. that we isolated would probably be limited to times or to depths where UV-B exposure was minimal (such as October when the ciliates were isolated). Clearly, UV levels in the surface waters of Lake Giles in June could lead to population declines for Cyclidium sp. without inhibiting growth in Glaucoma sp. (Table 4). Taken together, these data suggest that even at current levels of UV radiation, community structure of protists in clear oligotrophic lakes and oceans is likely to be influenced by ambient UV-B. Predicting the interactive effects of climate change and increased levels of UV-B radiation due to ozone depletion on protistan populations is beyond the scope of these laboratory-based experiments. It is reasonable to expect, however, that global climate change will modify UV-temperature relationships in aquatic systems in several ways including alteration of seasonal temperatures, ice-out, and vertical mixing (MacFadyen et al. 2004). While information from a few species or a single trophic level must be applied with care in predicting the effects of UV radiation on pelagic food webs (Wickham \& Carstens 1998, Mostajir et al. 1999), heterotrophic protists play a central role in pelagic food webs (Müller 1989, Sanders et al. 1989, Weisse et al. 1990); consequently, levels of UV-B that are inhibitory or fatal to protists could alter the transfer of energy between trophic levels and result in indirect impairment of the other populations that depend on the functions of these microorganisms.

Acknowledgements. We thank C. E. Williamson for advice on construction of the UV-lamp phototron and for determining the spectral composition of the damaging and repair radiation for our lamps, P. J. Neale for conversion factors to calculate Setlow weighting of the UV-B lamp, and A.-C. Olsson Allen for laboratory assistance. We also thank the Blooming Grove Hunting and Fishing Club for allowing access to Lake Giles. This research was supported by NSF grants DEB-9973758 and DEB-IRCEB-0210972.

\section{LITERATURE CITED}

Arts MT, Robarts RD, Kasai F, Waiser MJ, Tumber VP, Plante AJ, Rai H, Lange HJD (2000) The attenuation of ultraviolet radiation in high dissolved organic carbon waters of wetlands and lakes on the northern Great Plains. Limnol Oceanogr 45:292-299

Barcelo JA, Calkins J (1979) Positioning of aquatic microorganisms in response to visible light and simulated solar UV-B irradiation. Photochem Photobiol 29:75-83

Blaustein AR, Hoffman PD, Hokit DG, Kiesecker JM, Walls SC, Hays JB (1994) UV repair and resistance to solar UV$\mathrm{B}$ in amphibian eggs: a link to population declines? Proc Natl Acad Sci USA 91:1791-1795

Bothwell ML, Sherbot D, Pollock CM (1994) Ecosystem response to solar Ultraviolet-B radiation: influence of trophic-level interactions. Science 265:97-100

Cadet J, Vigny P (1990) The photochemistry of nucleic acids. In: Morrison H (ed) Bioorganic photochemistry, photochemistry of the nucleic acids, Vol 1. John Wiley, New York, p 1-272

Caron DA, Goldman JC, Fenchel T (1990) Protozoan respiration and metabolism. In: Capriulo GM (ed) Ecology of marine protozoa. Oxford University Press, New York, p 307-322 
Finlay BJ, Esteban GF, Olmo JL, Tyler PA (1999) Global distribution of free-living microbial species. Ecography 22: 138-144

Grad G, Williamson CE, Karapelou DM (2001) Zooplankton survival and reproduction responses to damaging UV radiation: a test of reciprocity and photoenzymatic repair. Limnol Oceanogr 46:584-591

Häder DP, Häder MA (1991) Effects of solar radiation on motility in Stentor coeruleus. Photochem Photobiol 54: $423-428$

Houghton JT, Ding Y, Griggs DJ, Noguer M, van der Linden PJ, Dai X, Maskell K, Johnson CA (eds) (2001) Climate change 2001: the scientific basis. Intergovernmental Panel on Climate Change. Cambridge University Press, Cambridge

Jeffrey SW, MacTavish HS, Dunlap WC, Vesk M, Groenewoud K (1999) Occurrence of UVA- and UVB-absorbing compounds in 152 species (206 strains) of marine microalgae. Mar Ecol Prog Ser 189:35-51

Jones RI, Rees S (1994) Influence of temperature and light on particle ingestion by the freshwater phytoflagellate Dinobryon. Arch Hydrobiol 132:203-211

Jürgens K, Pernthaler J, Schalla S, Amann R (1999) Morphological and compositional changes to a planktonic bacterial community in response to enhanced protozoan grazing. Appl Environ Microbiol 65:1241-1250

Karentz D, Cleaver JE, Mitchell DL (1991) Cell survival characteristics and molecular responses of Antarctic phytoplankton to ultraviolet-B radiation. J Phycol 27:326-341

Lenci F, Checcucci G, Ghetti F, Gioffrè D, Sgarbossa A (1997) Sensory perception and transduction of UV-B radiation by the ciliate Blepharisma japonicum. Biochim Biophys Acta 1336:23-27

Litchman E, Neale PJ, Banaszak AT (2002) Increased sensitivity to ultraviolet radiation in nitrogen-limited dinoflagellates: photoprotection and repair. Limnol Oceanogr 47: 86-94

MacFadyen EJ, Williamson CE, Grad G, Lowery M, Jeffrey WH, Mitchell DL (2004) Molecular response to climate change: temperature dependence of UV-induced DNA damage and repair in the freshwater crustacean Daphnia pulicaria. Global Change Biol 10:408-416

Madronich S, McKenzie RL, Bjorn LO, Caldwell MM (1998) Changes in the biologically active ultraviolet radiation reaching the Earth's surface. J Photochem Photobiol B 46: 5-19

Malloy KD, Holman MA, Mitchell D, Detrich HWI (1997) Solar UVB-induced DNA damage and photoenzymatic DNA repair in antarctic zooplankton. Proc Natl Acad Sci USA 94:1258-1263

Mitchell DL (1995) DNA damage and repair. In: Horspool W, Song PS (eds) A handbook of organic photochemistry and photobiology. CRC Press, London, p 1310-1315

Mitchell D (1996) Radioimmunoassay of DNA damaged by ultraviolet light. In: Pfeifer GP (ed) Technologies for detection of DNA damage and mutations. Plenum Press, New York, p 73-85

Mitchell DL (2004) DNA damage induced by ultraviolet radiation. In: Meyers RA (ed) Encyclopedia of molecular cell biology and molecular medicine, Vol 3. John Wiley \& Sons, New York, p 1-34

Mitchell DL, Karentz D (1993) The induction and repair of DNA photodamage in the environment. In: Young AR, Björn LO, Moan J, Nultsch W (eds) Environmental UV photobiology. Plenum Press, New York, p 345-347

Modenutti BE, Balseiro EG, Moeller R (1998) Vertical distribution and resistance to ultraviolet radiation of a planktonic ciliate, Stentor araucanus. Verh Int Ver Limnol 26: 1636-1640

Moeller RE, Gilroy S, Williamson CE, Grad G, Sommaruga R (2005) Dietary acquisition of photoprotective compounds (mycosporine-like amino acids, carotenoids) and acclimation to ultraviolet radiation in a freshwater copepod. Limnol Oceanogr 50:427-439

Morris DP, Zagarese H, Williamson CE, Balseiro EG, Hargreaves BR, Modenutti B, Moeller R, Queimalinos C (1995) The attenuation of solar UV radiation in lakes and the role of dissolved organic carbon. Limnol Oceanogr 40: 1381-1391

Mostajir B, Demers S, De Mora S, Belzile C and 9 others (1999) Experimental test of the effect of ultraviolet-B radiation in a planktonic community. Limnol Oceanogr 44: $586-596$

Müller H (1989) The relative importance of different ciliate taxa in the pelagic food web of Lake Constance. Microb Ecol 18:261-273

Neale PJ, Banaszak AT, Jarriel CR (1998a) Ultraviolet sunscreens in Gymnodinium sanguineum (Dinophyceae): mycosporine-like amino acids protect against inhibition of photosynthesis. J Phycol 34:928-938

Neale PJ, Cullen JJ, Davis RF (1998b) Inhibition of marine photosynthesis by ultraviolet radiation: variable sensitivity of phytoplankton in the Weddell-Scotia confluence during the austral spring. Limnol Oceanogr 43:433-448

Ochs CA (1997) Effects of UV radiation on grazing by two marine heterotrophic nanoflagellates on autotrophic picoplankton. J Plankton Res 19:1517-1536

Ochs CA, Eddy LP (1998) Effects of UV-A (320 to 399 nanometers) on grazing pressure of a marine heterotrophic nanoflagellate on strains of the unicellular Cyanobacteria Synechococcus spp. Appl Environ Microbiol 64: 287-293

Pakker H, Martins RST, Boelen P, Buma AGJ (2000) Effects of temperature on the photoreactivation of ultraviolet-Binduced DNA damage in Palmaria palmata (Rhodophyta). J Phycol 36:334-341

Pienitz R, Vincent WF (2000) Effect of climate change relative to ozone depletion on UV exposure in subarctic lakes. Nature 404:484-487

Rae R, Vincent WF (1998) Effects of temperature and UV radiation on microbial food web structure; potential responses to global change. Freshw Biol 40:747-758

Rex M, Harris NRP, Gathen Pvd, Lehmann R and 20 others (1997) Prolonged stratospheric ozone loss in the 1995-96 Arctic winter. Nature 389:835-838

Rocco VE, Oppezzo O, Pizarro R, Sommaruga R, Ferraro M, Zagarese HE (2002) Ultraviolet damage and counteracting mechanisms in the freshwater copepod Boeckella poppei from the Antarctic peninsula. Limnol Oceanogr 47:829-836

Sanders RW, Wickham SA (1993) Planktonic protozoa and metazoa: predation, food quality and population control. Mar Microb Food Webs 7:197-223

Sanders RW, Porter KG, Bennett SJ, DeBiase AE (1989) Seasonal patterns of bacterivory by flagellates, ciliates, rotifers, and cladocerans in a freshwater planktonic community. Limnol Oceanogr 34:673-687

Sanders RW, Porter KG, Caron DA (1990) Relationship between phototrophy and phagotrophy in the mixotrophic chrysophyte Poterioochromonas malhamensis. Microb Ecol 19:97-109

Schindler DW, Curtis PJ, Parker BP, Stainton MP (1996) Consequences of climate warming and lake acidification for UV-B penetration in North American boreal lakes. Nature 379:705-708 
Setlow RB (1974) The wavelengths in sunlight effective in producing skin cancer: a theoretical analysis. Proc Natl Acad Sci USA 71:3363-3366

Shindell DT, Rind D, Lonergan P (1998) Increased polar stratospheric ozone losses and delayed eventual recovery owing to increasing greenhouse-gas concentrations. Nature 392:589-592

Smith-Sonneborn J (1979) DNA repair and longevity assurance in Paramecium teteurelia. Science 203:1115-1117

Sommaruga R, Buma AGJ (2000) UV-induced cell damage is species-specific among aquatic phagotrophic protists. J Eukaryot Microbiol 47:450-455

Sommaruga R, Oberleiter A, Psenner R (1996) Effect of UV radiation on the bacterivory of a heterotrophic nanoflagellate. Appl Environ Microbiol 62:4395-4400

Weisse T, Müller H, Pinto-Coelho RM, Schweizer A, Springmann D, Baldringer G (1990) Response of the microbial loop to the phytoplankton spring bloom in a large prealpine lake. Limnol Oceanogr 35:781-794

Editorial responsibility: John Dolan, Villefranche-sur-Mer, France
Wickham S, Carstens M (1998) Effects of ultraviolet-B radiation on two arctic microbial food webs. Aquat Microb Ecol 16:163-171

Williamson CE, Neale PJ, Grad G, De Lange HJ, Hargreaves BR (2001) Beneficial and detrimental effects of UV on aquatic organisms: implications of spectral variation. Ecol Appl 11:1843-1857

Williamson CE, Grad G, De Lange HJ, Gilroy S, Karapelou DM (2002) Temperature-dependent ultraviolet responses in zooplankton: implications of climate change. Limnol Oceanogr 47:1844-1848

Zagarese HE, Tartarotti B, Anon Suarez DA (2003) The significance of ultraviolet radiation for aquatic animals. In: Ambasht RS, Ambasht NK (eds) Modern trends in aquatic ecology. Kluwer Academic, New York, p 173-200

Zepp RG, Callaghan TV, Erickson DJ III (2003) Interactive effects of ozone depletion and climate change on biogeochemical cycles. Photochem Photobiol Sci 2:51-61

Submitted: March 31, 2005; Accepted: July 1, 2005

Proofs received from author(s): September 20, 2005 